\title{
Immune Responses of Wistar Rat (Rattus novergicus) on Adduction of Humid Acid from Borneo Peat Soil
}

\author{
${ }^{\otimes}$ Diah Wulandari Rousdy, Rahmawati, Rikhsan Kurniatuhadi
}

DOI: 10.15294/biosaintifika.v8i3.7499

Department of Biology, Faculty of Mathematics and Natural Sciences, Universitas Tanjungpura, Pontianak, Indonesia

\section{History Article \\ Received 10 October 2016 Approved 6 November 2016 Published 24 December 2016}

\section{Keywords:}

humic acid; peat soil; immunostimulant

\begin{abstract}
Peat soil is a type of soil that dominates the island of Borneo. Typical compounds in peat soil is humic acid. Various in vitro studies performed have shown peat subtropical humic compounds can stimulate the immune system. However, in vivo study on animal has not been done. This study aimed to determine the effect of humic acid extracted from peat soil of Borneo against the immune system, both of non-specific and specific immunity Wistar rats (Rattus novergicus). Research using a completely randomized design with five treatments and five replicates, the normal controls, a positive control (isoprinosine), humic acid $125 ; 250 ; 500 \mathrm{mg} / \mathrm{kg}$. Humic acid was administered orally for 10 days. The results showed humic acid adduction did not significantly affect levels of hemoglobin, erythrocytes and hematocrit. Humic acid adduction of $125 \mathrm{mg} / \mathrm{kg}$ significantly affects the total leukocyte count and differential leukocyte. Humic acid $125 \mathrm{mg} / \mathrm{kg}$ also showed increased phagocytic index better than normal controls. All humic acid treatments do not provide a significant effect on the total amount of antibody. The results of this study can be used for the development of Borneo tropical peat resources as natural imunostimulant.
\end{abstract}

\section{How to Cite}

Rousdy, D. W., Rahmawati, R. \& Kurniatuhadi, R. (2016). Immune Responses of Wistar Rat (Rattus novergicus) on Adduction of Humid Acid from Borneo Peat Soil. Biosaintifika: Journal of Biology \& Biology Education, 8(3), 400-405.

(c) 2016 Universitas Negeri Semarang
Correspondence Author:

J1. Prof. Dr. H. Hadari Nawawi Pontianak 78111

E-mail: diah.w.rousdy@gmail.com
p-ISSN 2085-191X

e-ISSN 2338-7610 


\section{INTRODUCTION}

Indonesia is the fourth largest country with an area of tropical peatlands by 26 million hectares. However, the use of tropical peatlands in Indonesia has not developed like the use of peat in subtropical countries. Distribution of peatlands in Indonesia is mostly located in Kalimantan, Sumatra and Papua. In this case, Kalimantan has for about 5.8 million hectares (Wahyunto \& Suryadiputra, 2008). The humic acid compound in peat soil has a very complex structure and it's different for each type of soil. Tropical peat soil in Indonesia has different chemical characteristics from peat soil in a subtropical area (Stevenson, 1994). Different characteristics of both the humic acids indicate differences in the functions of both the humic acids.

The humic acid compound of subtropical countries was reported be used in various fields such as chemical industry, environment and health. In the health sector, humic acid compounds from subtropical peat soils have been known as an antibacterial, antiviral, antitumor, promote growth and development of livestock and potentially as an immunostimulant (Agazzi et al., 2007; Chen et al., 2003; Kodama \& Denso, 2007; Tohid et al., 2010).

Research on the effect of the humic extract on the immune system, in vitro assay showed increased production of several cytokines (Joone et al., 2003; Junek et al., 2009) and improved the adhesion of neutrophils (Chen et al., 2003). Effect of humic acid from peat Kalimantan through supplementation in fish feed has been done by Rousdy (2013) showed an increase in the total antibody, total leukocyte count and phagocytic activity.

Mammalian immune systems are more complex than Pisces immune systems. Based on the research that has been done before, the study aims to determine the potency of natural immunostimulant of humic acid from peat soil against Wistar rats (Rattus novergicus).

\section{METHODS}

The research was conducted by using a completely randomized design with five treatments and five replicates namely a normal control, a positive control using standart immunostimulant drug (isoprinosine), humic acid doses of $125 ; 250 ; 500 \mathrm{mg} \mathrm{kg}^{-1}$. Provision of humic acid made orally for 10 days. Measurement of hematologic and immune parameters were done on the $10^{\text {th }}$ day after being given humic acid.
Humic acid extraction method refers to IHSS method (2012) that is based on strong acid precipitation and solubility in a weak base. Peat soil, which had been cleared of gravel and plant roots, weighed 40 grams and extracted with 400 $\mathrm{mL}$ of $0.1 \mathrm{M} \mathrm{NaOH}$ for 4 hours while was shaken using a shaker. The mixture was deposited for one night. The filtrate was taken and filtered several times with cotton.

The filtrate was added to a solution of 6 $\mathrm{M} \mathrm{HCl}$ acid until $\mathrm{pH} 2$. Then the filtrate was shaken using a shaker and deposited for one night. The filtrate was centrifuged again (3500 rpm for 20 minutes) to separate the humic acid fraction (sediment) and fulvic acids (supernatant). Centrifugation was repeated several times until the separation is complete in order to obtain sediment humic acids. Then the humic acid extract was made in a predetermined concentration.

Measurement of hematologic parameters was done on the $10^{\text {th }}$ day after being given humic acid. Rats were anesthetized with chloroform. Blood samples were taken from the rat heart (cardiac puncture) and were accommodated in microtube contain EDTA as anticoagulant. The number of leukocytes and erythrocytes was calculated by hemocytometer. The $\mathrm{Hb}$ level was determined by the Sahli method. The percentage of hematocrit was measured using hematocrit tubes centrifuge. Tubes were centrifuge at 10,000 rpm for 2 minutes. The differential white blood cell was calculated using smeared blood cell preparat with Giemsa dye (Gunarso, 1989). Differential white blood cells were differentiated into lymphocytes, monocytes, neutrophils, basophils and eosinophil then displayed as a percentage.

After 10 days, all rats were injected intraperitoneally with $1 \mathrm{~mL}$ suspension of Staphylococcus aureus and incubated foranhour. Rats were anesthetized with chloroform and then dissected in abdomen. Peritoneal fluid was taken using a micropipette. Peritoneal fluid was smeared on glass objects and fixed with methanol. After drying, smeared object was stained by Giemsa and dried until 20 minutes, then it was rinsed with running water. Macrophage cells were observed and counted under oil immersion using a microscope with a magnification (10x-100x). Phagocytic activity which was determined by the number of phagocytic cells are active phagocytosis in phagocytic cells 100 (Kusmardi et al., 2007).

Neutrophil cell activity measurements were conducted using NBT-glass adherent assay. Blood sample $0.1 \mathrm{~mL}$ was dropped on the slide and incubated on top of the wet paper at room temperature for 30 minutes. The object glasses 
were washed with PBS solution. One drop of $0.2 \%$ NBT was dropped on the slide and the cover slip was placed on it, and then reincubated for 30 minutes. Active neutrophil cells contain bluish granules, while inactive neutrophils do not have bluish granules. In addition, active neutrophil cells are large and spherical. Active neutrophil cells were counted at 400x magnification and displayed in the number of cells per field of view (Ispir \& Dorucu, 2005).

Blood samples were kept frozen or clot for 1-2 hours and centrifuged at $3000 \mathrm{rpm}$ for $10 \mathrm{~min}$ utes, then the serum (supernatant) was taken.A total of $50 \mathrm{~mL}$ of blood serum of mice was diluted into $50 \mu \mathrm{L}$ PBS on microwell plate. Furthermore, each well was added $50 \mathrm{~mL}$ suspension of Staphylococcus aureus and mixed well for $5 \mathrm{~min}$ utes, incubated at $37^{\circ} \mathrm{C}$ for 60 minute then incubated overnight at room temperature. Positive agglutination was characterized by the formation of white clouds on micro-titration wels (Emelda et al., 2015).

\section{RESULTS AND DISCUSSION}

The humic substance is a major is component of humus in the peat soil. Humic formed from the organic material through decomposition of plants. The humic acid is one of the main constituents of the humic compounds that was soluble in alkaline $\mathrm{pH}$. Giving of humic acid extracted from peat soil to Wistar rats provide some immune enhancement effect.

After being given by the humic acids orally for 10 days, hemoglobin $(\mathrm{Hb})$, total erythrocytes and hematocritare not significantly different between treatment groups $(P>0.05)$ (Table 1$)$. Hemoglobin value, erythrocytes and hematocrit in humic acid treatment was still within the normal range. The results showed oral administration of humic acid did not cause unexpected side effects. Meanwhile, the number of leukocytes showed a significant difference among humic acid treatments $(P<0.05)$. The humic acid treatment dose of $125 \mathrm{mg} \mathrm{kg}^{-1}$ showed the highest leukocyte counts than other treatments.

Humic acid treatment provides an increased number of total leukocytes, especially at $125 \mathrm{mg} \mathrm{kg}^{-1}$ dose. Increasing in the number of leukocytes might be caused by the proliferative effect of humic acid on leukocyte through the production of cytokines ( Joone et al., 2003) . Cytokines are proteins that play the role in intercellular communication, especially communication between leukocytes. Cytokines are produced by leukocytes, notably macrophages, which then triggered mobilization and increase the number of leukocytes in the blood ( Janeway et al., 2001).

Differential leukocyte count showed the percentage of lymphocytes and neutrophils for humic acid $125 \mathrm{mg} \mathrm{kg}^{-1}$ significantly different $(P<0.05)$ from normal controls, isoprinosine and humic acid $250 \mathrm{mg} \mathrm{kg}^{-1}$ and $500 \mathrm{mg} \mathrm{kg}^{-1}$ (Table 2). Humic acid treatment of $125 \mathrm{mg} \mathrm{kg}^{-1}$ dose gives a higher number of neutrophil and a lower lymphocyte count than other treatment. This means that the $125 \mathrm{mg} \mathrm{kg}^{-1}$ doses can stimulate innate immunity system through increased proliferation of the number of neutrophils. But this dose do not give stimulus to the adaptive immune system is indicated by the lower number of lymphocytes count.

Innate immune system parameter could be seen from the number of active neutrophils and phagocytic index. While, the adaptive immune system parameter could be seen from the number of total antibody. Active neutrophils counted after adduction of humic acid was significantly different from the normal control group, but not

Table 1. Hematology parameter after humic acid administration

\begin{tabular}{lcccc}
\hline Treatment & Hemoglobin (g/dl) & Hematocrit (\%) & $\begin{array}{c}\text { Total erythrocytes } \\
(\mathrm{sel} / \mathrm{ml})\end{array}$ & $\begin{array}{c}\text { Total } \\
\text { leukocyte }(\mathrm{sel} / \mathrm{ml})\end{array}$ \\
\hline $\begin{array}{l}\text { Normal control } \\
\text { Isoprinosin }\end{array}$ & $11.88 \pm 1.25^{\mathrm{a}}$ & $39.36 \pm 5.45^{\mathrm{a}}$ & $4,912,400 \pm 301,222^{\mathrm{a}}$ & $4,020 \pm 335^{\mathrm{a}}$ \\
$\begin{array}{l}\text { control } \\
\text { Humic acid 125 }\end{array}$ & $10.52 \pm 0.20^{\mathrm{a}}$ & $39.92 \pm 6.27^{\mathrm{a}}$ & $4,766,600 \pm 572,602^{\mathrm{a}}$ & $4,280 \pm 269^{\mathrm{ab}}$ \\
$\mathrm{mg} \mathrm{kg}^{-1}$ & $11.44 \pm 0.32^{\mathrm{a}}$ & $39.94 \pm 3.82^{\mathrm{a}}$ & $5,067,400 \pm 581,369^{\mathrm{a}}$ & $5,570 \pm 1665^{\mathrm{b}}$ \\
$\begin{array}{l}\text { Humic acid 250 } \\
\mathrm{mg} \mathrm{kg}^{-1}\end{array}$ & $11.12 \pm 0.51^{\mathrm{a}}$ & $42.82 \pm 6.89^{\mathrm{a}}$ & $4,491,600 \pm 706,209^{\mathrm{a}}$ & $5,150 \pm 506^{\mathrm{ab}}$ \\
$\begin{array}{l}\mathrm{Humic}^{\mathrm{a}} \text { acid 500 } \\
\mathrm{mg} \mathrm{kg}^{-1}\end{array}$ & $11.12 \pm 0.63^{\mathrm{a}}$ & $38.8 \pm 3.94^{\mathrm{a}}$ & $4,723,600 \pm 287,571^{\mathrm{a}}$ & $5,195 \pm 446^{\mathrm{ab}}$ \\
\hline
\end{tabular}

Data performed as average \pm standard deviation. Different value in the same column showed significant difference between treatment $(P<0,05)$ 
Table 2. Differential leucocytes after humic acid administration

\begin{tabular}{lccccc}
\hline Treatments & $\begin{array}{c}\text { Lymphocyte } \\
(\%)\end{array}$ & $\begin{array}{c}\text { Monocyte } \\
(\%)\end{array}$ & $\begin{array}{c}\text { Neutrophil } \\
(\%)\end{array}$ & $\begin{array}{c}\text { Eosinophil } \\
(\%)\end{array}$ & $\begin{array}{c}\text { Basophil } \\
(\%)\end{array}$ \\
\hline Normal control & $69.8 \pm 9.3^{\mathrm{a}}$ & $10.6 \pm 2.8^{\mathrm{a}}$ & $16.4 \pm 6.6^{\mathrm{a}}$ & $2.2 \pm 1.7^{\mathrm{a}}$ & $1.0 \pm 0.6^{\mathrm{a}}$ \\
Isoprenosine control & $69.8 \pm 9.3^{\mathrm{a}}$ & $10.6 \pm 1.2^{\mathrm{a}}$ & $16.2 \pm 8.0^{\mathrm{a}}$ & $2.8 \pm 2.0^{\mathrm{a}}$ & $1.0 \pm 1.3^{\mathrm{a}}$ \\
Humic acid $125 \mathrm{mg} \mathrm{kg}{ }^{-1}$ & $59.0 \pm 10.6^{\mathrm{b}}$ & $10.2 \pm 3.1^{\mathrm{a}}$ & $26.4 \pm 6.7^{\mathrm{b}}$ & $4.4 \pm 2.4^{\mathrm{a}}$ & $0.2 \pm 0.4^{\mathrm{a}}$ \\
Humic acid $250 \mathrm{mg} \mathrm{kg}^{-1}$ & $65.2 \pm 16.9^{\mathrm{a}}$ & $10.6 \pm 4.6^{\mathrm{a}}$ & $20.0 \pm 12.4^{\mathrm{a}}$ & $3.2 \pm 1.2^{\mathrm{a}}$ & $1.0 \pm 0.9^{\mathrm{a}}$ \\
Humic acid 500 mg kg-1 & $66.8 \pm 14.2^{\mathrm{a}}$ & $10.2 \pm 3.3^{\mathrm{a}}$ & $19.4 \pm 11.9^{\mathrm{a}}$ & $3.2 \pm 2.7^{\mathrm{a}}$ & $0.4 \pm 0.5^{\mathrm{a}}$ \\
\hline
\end{tabular}

Data performed as average \pm standard deviation. Different value in the same column showed significant difference between treatment $(P<0.05)$

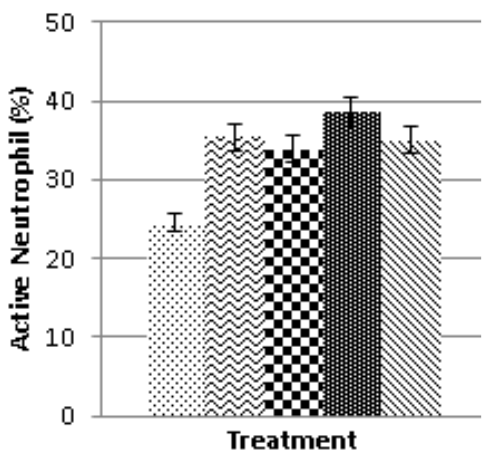

A

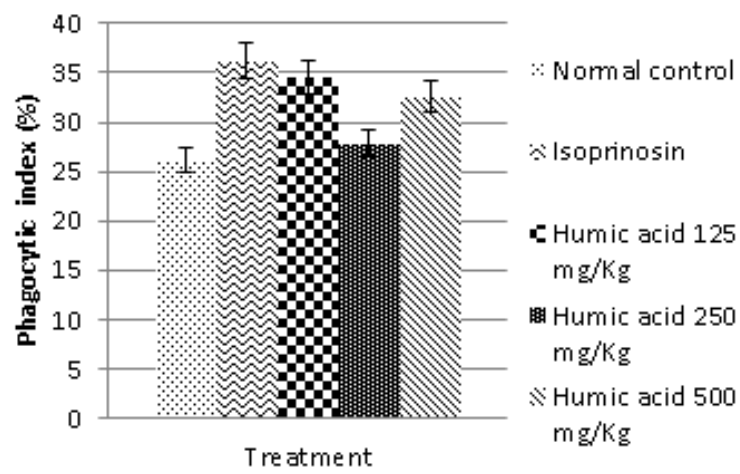

B

Figure 1. The number of active neutrophil (a), phagocytic index (b) after humid acid adduction

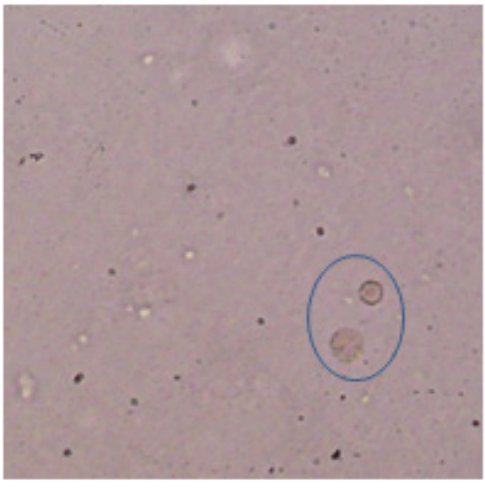

A

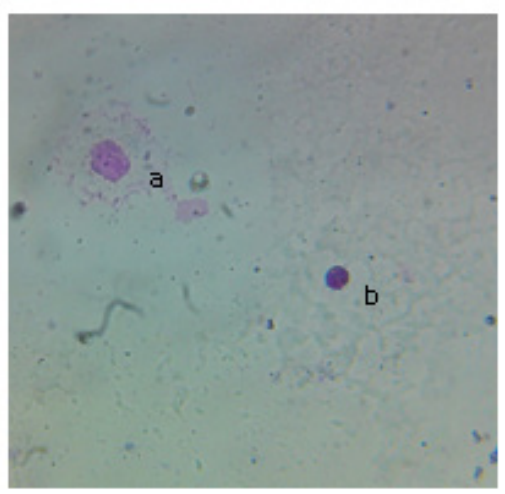

B

Figure 2. A: active neutrophil has spherical granule in cytoplasm; B: Phagocytic macrophag (a), Nonphagocytic macrophage (b)

significantly different $(P<0.05)$ with isoprinosin group (Figure 1a). Phagocytic index of humic acid treatment was also not significantly different from the isoprinosine but still significantly different from normal controls group (Figure 1B).

The parameter of immune system results indicated humic acid administration could stimulate the activity of neutrophil and phagocytic index better than normal controls, but not significantly different from standard drug treatment, isoprinosin. Determination number of neutrophils with the NBT-adherent cell method is aimed to determine the active neutrophils. Active neutrophil cells were able to adhesion on vascular intima surface before diapedesis. Microscopic observation of active neutrophil also characterized by the presence many spherical granules in the cytoplasm (Figure 2A). Neutrophil granules are containing oxidative radicals that kill antigens after phagocytosis (Davies, 1997).

Neutrophil adhesion process was the first step in leukocytes migration to the site of infection. The results are consistent with Chen et al. (2003) research that humic acid can improve the 
adhesion of neutrophils to the blood vessels thereby increasing the ability of neutrophil chemotaxis and increase neutrophils pool in the blood. The Chen et al. (2003) also added that the activation of NF- $\mathrm{KB}$ cellular signals caused by adduction of humic acid. Activation of NF-KB modulates transcription of genes coding for the synthesis of interleukins IL-2, IL-6, IL-8 and leukocytes cell adhesion molecules (cell adhesion molecule, CAM). Secretion of cytokines was also reported by Vetvitcka et al. (2010) which states that application humic acid with glucan (ratio 1:1) can stimulate the secretion of six types cytokines IL-2, IL-4, IL5 , IL- 6, TNF- $\alpha$, and MPC- 1 . Thus, the role of humic acid in improving the adhesion of neutrophils thought to relate to the regulation of signal transduction pathways that neutrophil activation.

Phagocytic cells are the most important cellular components of the innate immune system. Phagocytic activity is a primitive defense mechanism and an important characteristic of the non-specific immune system (Davies, 1997). Phagocytic activity was shown by phagocytic index. The highest phagocytic index was given by isoprinosin treatment (Figure 1B). However, adduction of humic acids could improve phagocytic activity nearly equal with the standard drug, the isoprinosine.

During the process of phagocytosis, foreign antigens ( $S$. aureus bacteria) will attach to specific receptors on the surface of phagocytic cells (macrophages). This process then followed by the ingestion of antigen and formation of the phagosome. Particles in phagosome then destroyed by radical oxidative (ROS) production. Microscopic observation was shown during phagocytosis, macrophages would form pseudopodia and $S$. aureus bacteria appear in the cytoplasm of macrophages (Figure 2B).

Enhancement of phagocytic activity of macrophages by adduction of humic acid might becaused by the production of ROS (reactive oxygen species). Macrophage cells that phagocytes foreign particles would makeincreasing in oxygen consumption (Yuniastuti et al., 2010). The oxygen is reduced to $\mathrm{O}_{2}{ }^{-}$(radical oxidative) by NADPH oxidase, an complex enzyme found in the plasma membrane of phagocytic cells. The active neutrophils secrete ROSand measured with NBT reduction assay. During phagocytosis, repiratory burst will occur and followed by formation of superoxide anion. Thus reduced NBT and formed blue color formazan that reflected in neutrophil granules.

The humic acid adduction did not stimulate the production of antibodies, although the levels are slightly higher than normal controls. The value of total antibody titers between the control group and the humic acid treatment was not significantly different $(P>0,05)$ (Figure 3$)$.

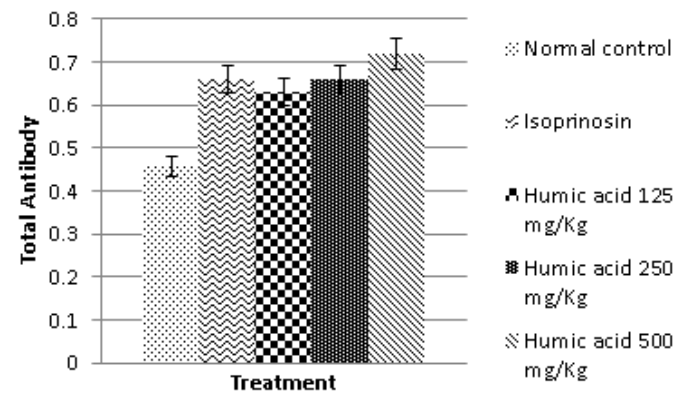

Figure 3. Total amount of antibody after humid acid adduction

Specific or adaptive immunity mediated by antibodies production. Antibodies or immunoglobulin include the humoral elements that produce by lymphocytes. Results of this study showed that humic acid did not stimulate antibodies production. The level of antibodies titer did not different among all treatment and control group (Figure 3). Although, the total antibodies in humic acid is slightly higher than normal controls. This result occurred because the rats had never been exposed to antigen (S. aureus) beforehand. Significant antibody production will occur when the rats produce lymphocytes memory cell by previous infection (Janeway et al., 2001).

The antibody titer calculation results was consistent with the differential leukocytes count (Table 2). It showed humic acid adduction of 125

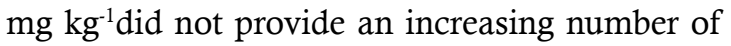
lymphocytes that play a role in the formation of antibodies, but is able to increase the number of monocytes that play a role in non-specific immunity. This study indicates humic acid from peat soil was able to stimulus nonspecific immune system which is mainly role by neutrophils and macrophages but does not stimulate specific immune system which role by lymphocytes. The results of this study useful for the development of Borneo tropical peat resources as natural imunostimulant.

\section{CONCLUSION}

This research concluded that humic acid adduction had no significant effect on hemoglobin levels, erythrocyte, hematocrit and total antibody. Humic acid adduction dose of $125 \mathrm{mg}$ $\mathrm{kg}^{-1}$ significantly affect the total leukocyte count 
and differential leukocyte. Humic acid $125 \mathrm{mg}$ $\mathrm{kg}^{-1}$ also showed enhancement of phagocytosis and neutrophil activity and almost same with isoprinosin, as standard immunostimulant drug. This research is expected to provide scientific information about the potential of humic acid as a natural immunostimulant, based on the utilization tropical peat resources.

\section{ACKNOWLEDGEMENT}

This research was supported by Grand Dosen Pemula 2015, Ministry of Research, Technology and Higher Education, Indonesia

\section{REFERENCES}

Agazzi, A., Cigalino, G., Mancin, G., Savoini, G., \& Dell'Orto, V. (2007). Effects of dietary humates on growth and an aspect of cell-mediated immune response in newborn kids. Small Ruminant Research, 72(2), 242-245.

Chen, C. H., Liu, J. J., Lu, F. J., Yang, M. L., Lee, Y., $\&$ Huang, T. S. (2002). The effect of humic acid on the adhesibility of neutrophils. Thrombosis research, 108(1), 67-76.

Davies, H. (1997). Introductary Immunobiology. London: Chapman and Hall.

Emelda, A., Rahman, S., \& Hardianti, H. (2015). Efek Imunostimulan Infus Buah Mahkota Dewa (Phaleria macrocarpa (Scheff.) Boerl.) Asal Kab. Sidrab Sulawesi Selatan Terhadap Sekresi Antibodi Tikus Putih (Rattus norvegicus) Jantan Dengan Teknik Hemaglutinasi. Journal of Tropical Pharmacy and Chemistry, 3(1), 37-41

Gunarso, W. (1989). Mikroteknik. Bogor: Departemen Pendidikan dan Kebudayaan Direktorat Jenderal Pendidikan Tinggi, Pusat Studi Ilmu Hayati, IPB

International Humic Substances Society (IHSS). (2012). Isolation of IHSS Soil Fulvic and Humic Acids. (www.humicsubstances.org).

İSPIR, Ü., \& Dörücü, M. (2005). A study on the effects of levamisole on the immune system of rainbow trout (Oncorhynchus mykiss, Walbaum). Turkish Journal of Veterinary and Animal Sciences, 29(5), 1169-1176.
Janeway, C. A., Travers, P., Walport, M., \& Shlomchik, M. J. (1999). Immunobiology. London: Garland Publishing.

Jooné, G. K., Dekker, J., \& Jansen van Rensburg, C. E. (2003). Investigation of the immunostimulatory properties of oxihumate. Zeitschrift für Naturforschung $C$, 58(3-4), 263-267.

Junek, R., Morrow, R., Schoenherr, J. I., Schubert, R., Kallmeyer, R., Phull, S., \& Klöcking, R. (2009). Bimodal effect of humic acids on the LPS-induced TNF- $\alpha$ release from differentiated U937 cells. Phytomedicine, 16(5), 470-476.

Kodama, H. (2007). Antitumor effect of humus extract on murine transplantable L1210 leukemia. Journal of Veterinary Medical Science, 69(10), 1069-1071.

Kusmardi, Kumala, S., \& Triana, E. E. (2007). EfekImunomodulatorEkstrakDaunKetepengCina (Cassia alata) Terhadap Aktivitas dan Kapasitas Fagositosis Makrofag. Makara Kesehatan, 11(2), 50-53

Rousdy, D. W. (2013). Respons Imunitas Ikan Mas (Cyprinus carpio Linn.) Pada Pemberian Asam Humat Tanah Gambut Kalimantan. Thesis.Yogyakarta: Universitas Gadjah Mada.

Stevenson, F. J. (1994). Humus Chemistry, Genesis, Composition, Reaction. New Jersey: John Willey \& Sons Inc.

Tohid, T., Hasan, G., \& Alireza, T. (2010). Efficacy of mannanoligosaccharides and humate on immune response to Avian Influenza (H9) disease vaccination in broiler chickens. Veterinary research communications, 34(8), 709-717.

Vetvicka, V., Baigorri, R., Zamarreno, A. M., GarciaMina, J. M., \& Yvin, J. C. (2010). Glucan and humic acid: Synergistic effects on the immune system. Journal of medicinal food, 13(4), 863-869.

Wahyunto, \& Suryadiputra, I. N. N. (2008). Peatland Distribution in Sumatra and Kalimantan: Explanation of Its Data Sets Including Source of Information, Accuracy, Data Constraints, and Gaps. Wetlands International, Indonesia Programme.

Yuniastuti, A., Nugrahaningsih, W. H., \& Zunikhah, Z. (2010). Efektivitas Seng (Zn) sebagai Imunostimulan dalam Produksi Reactive Oxygen Intermediate pada Mencit Balb/C yang Diinfeksi Salmonella typhimurium. Biosaintifika: Journal of Biology \& Biology Education, 2(1), 53-59 